\title{
Trends in Archaic and Woodland Period Use of the Middle Sabine River Basin Based on Dart Point Proportions
}

Timothy K. Perttula

Heritage Research Center, Stephen F. Austin State University

William L. Young

Follow this and additional works at: https://scholarworks.sfasu.edu/ita

Part of the American Material Culture Commons, Archaeological Anthropology Commons, Environmental Studies Commons, Other American Studies Commons, Other Arts and Humanities Commons, Other History of Art, Architecture, and Archaeology Commons, and the United States History Commons

Tell us how this article helped you.

This Article is brought to you for free and open access by the Center for Regional Heritage Research at SFA ScholarWorks. It has been accepted for inclusion in Index of Texas Archaeology: Open Access Gray Literature from the Lone Star State by an authorized editor of SFA ScholarWorks. For more information, please contact cdsscholarworks@sfasu.edu. 


\section{Trends in Archaic and Woodland Period Use of the Middle Sabine River Basin Based on Dart Point Proportions}

\section{Creative Commons License}

\section{(c) (1) \&}

This work is licensed under a Creative Commons Attribution-NonCommercial 4.0 International License 


\title{
Trends in Archaic and Woodland Period Use of the Middle Sabine River Basin Based on Dart Point Proportions
}

\author{
Timothy K. Perttula and William L. Young
}

\section{INTRODUCTION}

In this article, we use the varying proportions of a large sample of Archaic and Woodland period dart points to explore trends in settlement and occupational intensity from ca. 10,000 to 1200 years B.P. in the Pineywoods and Post Oak Savannah of East Texas (Figure 1). These darts were collected from sites in Gregg, Harrison, Rusk, and Smith counties, Texas, mainly on sites in the middle reaches of the Sabine River basin.

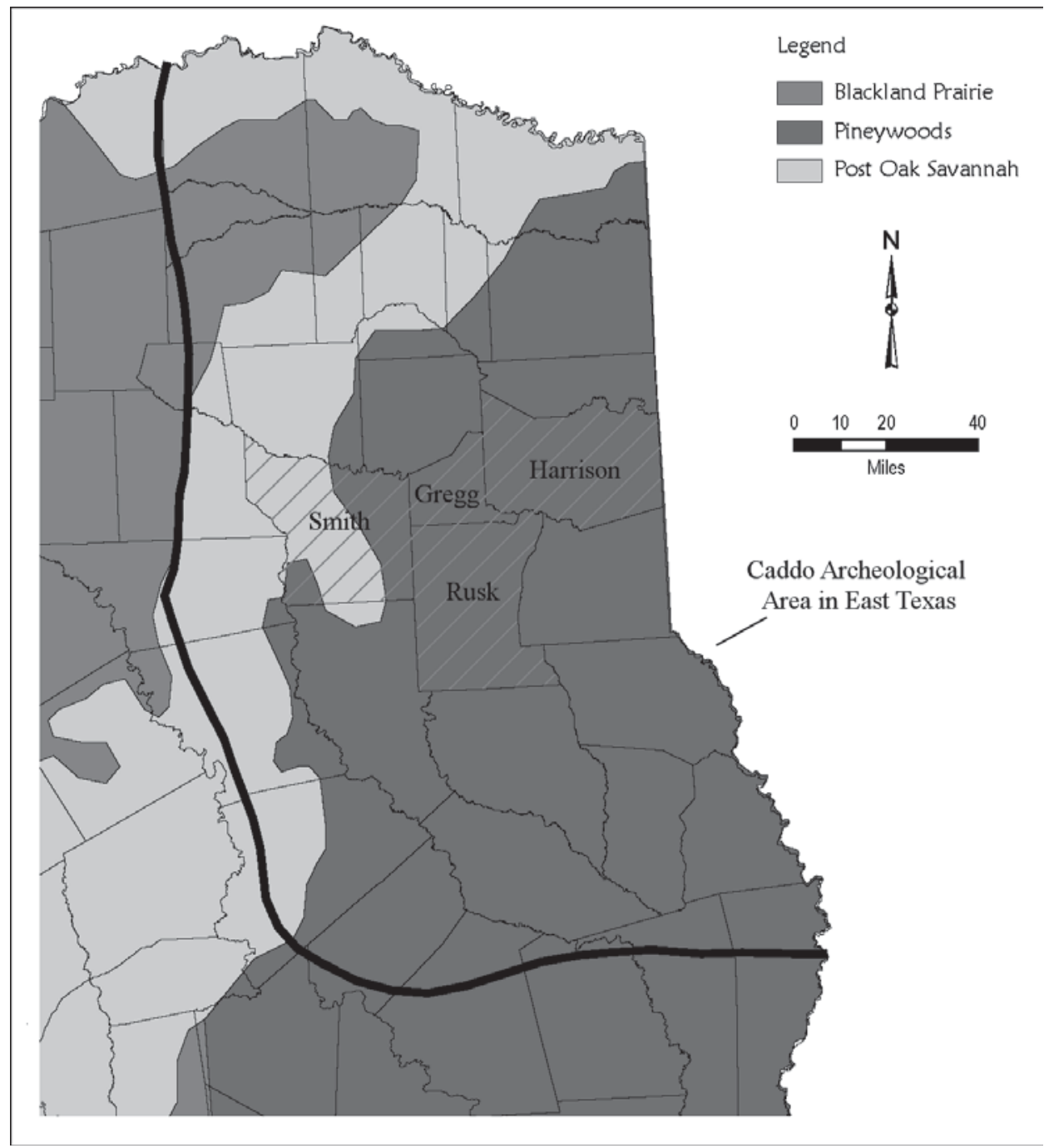

Figure 1. Location of Gregg, Harrison, Rusk and Smith counties in the East Texas Pineywoods. 


\section{THE DART POINT COLLECTION}

The more than 1280 dart points examined, categorized, and typologically identified for this study are from the Buddy Calvin Jones collection at the Gregg County Historical Museum in Longview, Texas. They are currently in about 20 frames (Figures 2 and 3). These points were collected from surface contexts by Buddy Calvin Jones in the 1950s and 1960s, and recorded by site and/or county proveniences.

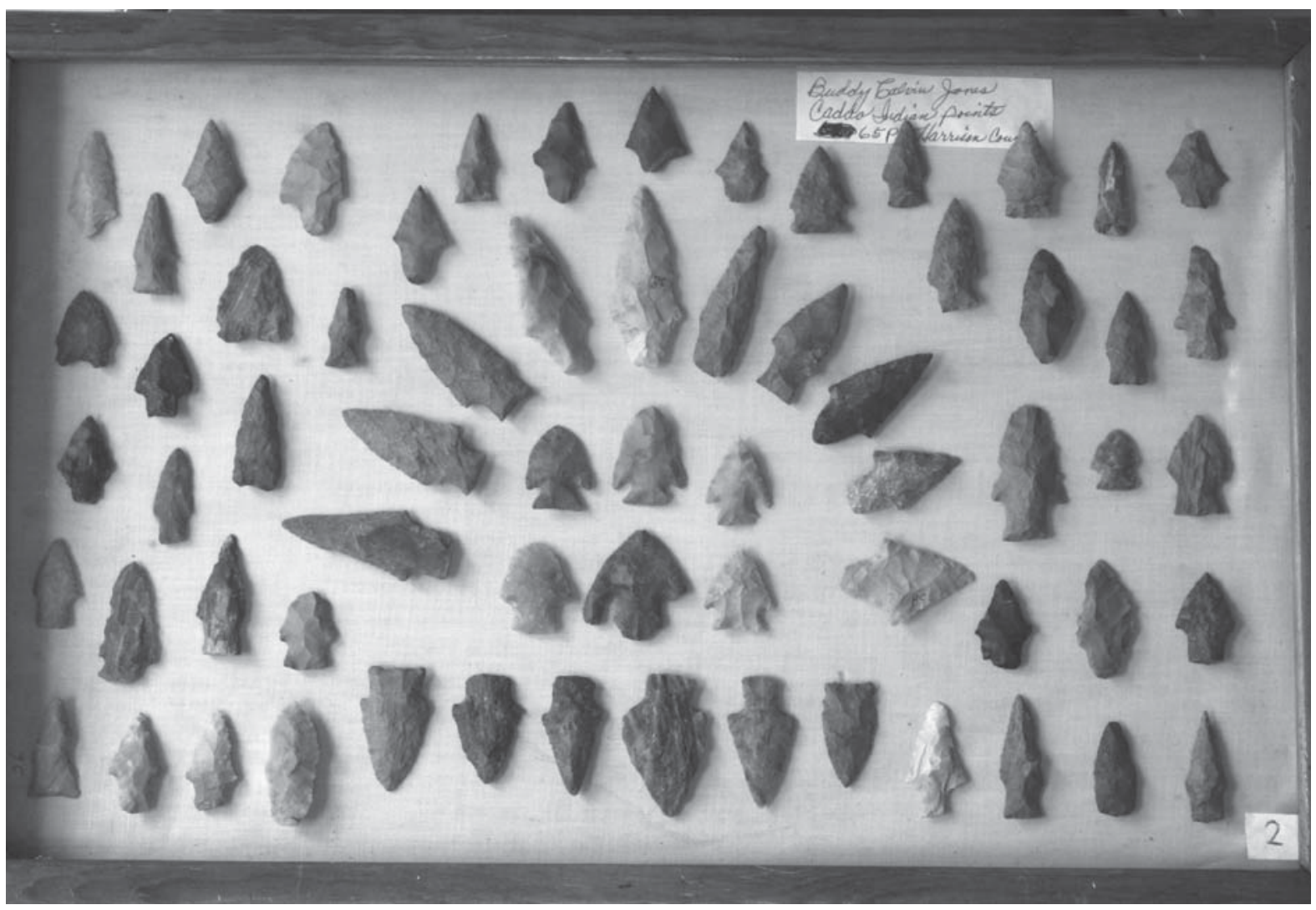

Figure 2. Buddy Calvin Jones Collection, Frame 2, Harrison County. Image reproduced courtesy of the Gregg County Historical Museum.

\section{POINT TYPES AND PERIOD ASSIGNMENTS}

For our purposes, the Archaic period in East Texas is defined as lasting from 10,000 years B.P. to approximately 2500 years B.P., with the Early Archaic dating from ca. 10,000-8000 years B.P. (8050-6050 B.C.), the Middle Archaic ranging from 8000-5000 years B.P. (6050-3050 B.C.), and the Late Archaic dating from 5000-2500 years B.P. (3050-550 B.C.). The Woodland period ranges from 2500-1150 years B.P. (550 B.C. to A.D. 800$)$.

Our proposed temporal ordering of dart points in the East Texas Archaic and Woodland periods draws first upon the few available absolute dates from East Texas on Archaic sites, as well as the known sequences of dart points in surrounding regions, such as Southwest Arkansas (Schambach 1998; Trubitt 2009), Northwest and Northern Louisiana (Girard 2000; Girard et al. 2011; Rees 2010; Saunders 2010), the Missouri Ozarks (Ray et al. 2009), and Central Texas (Collins 1998; Collins et al. 2011), and chronological periods of use offered by Turner and Hester (1999). A recent cladistics study (see O'Brien and Lyman 2003; Lipo et al. 2006) of 93 Texas dart point types that has plotted the statistical affinities among the various types (Carpenter and Paquin 2010:158 and Figures 2 and 3) was also relied upon for estimating temporal ages of dart 


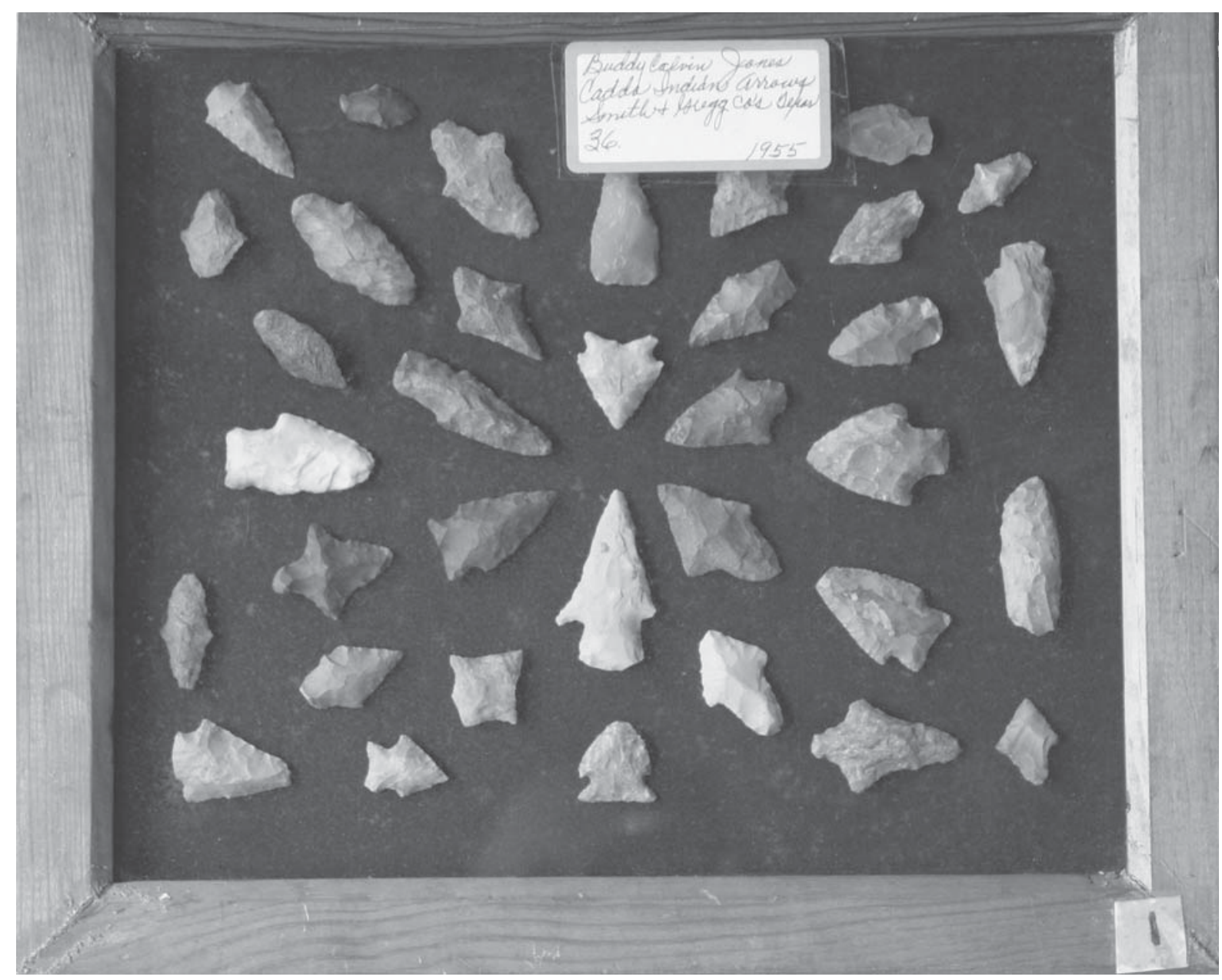

Figure 3. Buddy Calvin Jones Collection, Frame 1, Gregg and Smith Counties. Image reproduced courtesy of the Gregg County Historical Museum.

points. From these relationships, Carpenter and Paquin (2010:Figure 4) proposed hypothetical relationships between dart point types "based on overlap in temporal, spatial, and formal attributes."

Based on these various lines of evidence, as well as the suggested chronological sequences for East Texas dart points proposed by Story (1990:Figure 32) and Thurmond (1990:Table 8), the Early Archaic dart point sequence begins with Dalton and San Patrice points, although both point types were first made sometime prior to 10,000 years B.P. (Koldehoff and Walthall 2009: Ray et al. 2009) and are often considered to be diagnostic of the Late Paleoindian period in the broader region. Recent radiocarbon dates from the Big Eddy site in southwest Missouri indicates both points were made and used until ca. 9800 years B.P. (Ray et al. 2009:160), in the early years of the Late Paleoindian-Early Archaic technological, subsistence, and settlement/mobility transition. Later Early Archaic points (ca. 9800-9000 years B.P.) include the Breckenridge, Scottsbluff, and Keithville types (Webb 2000:4), as well as later Pelican, Graham Cave, and Rice Lobed points (ca. 8500-8000 years B.P.).

Proposed early Middle Archaic points in East Texas include the Hidden Valley and Kirk types, as well as the Palmer type, although these are points that are not particularly common in East Texas dart point assemblages (e.g., Jones 1957; Rogers and Perttula 2004; Furman and Amick 2006; Turner 2006:Table 7). Between 6500-5000 years B.P., Middle Archaic points are suggested to include the Cossatot, Johnson, Jakie Stemmed, White River side-notched points (sometimes referred to as Big Sandy points, see Ray and Lopinot 2003), Morrill, Bell and Andice (or Calf Creek), and the distinctive blade-notched Evans point. 
In the early part of the Late Archaic period (ca. 5000-4000 years B.P.), East Texas dart point assemblages may be expected to include Bulverde, Carrollton, Wells, Williams, and Trinity types, as well as Palmillas and Neches River. Dart points posited to date primarily to the latter part of the Late Archaic (ca. 3800-2500 years B.P.) include Yarbrough (although the dating evidence for this point type is contradictory on East Texas sites), Pontchartrain, Ellis, and Marshall types, as well as Dawson, Epps, and Motley types. The ubiquitous contracting stem Gary point appears to have been made and used beginning at the end of the Late Archaic (cf. Schambach 1998), but fully flourished as a dart point/knife throughout the later Woodland period, along with the Kent dart point type.

\section{PERIODS AND INTENSITY OF USE}

Assuming that the 1280+ dart points studied in the Buddy Calvin Jones collection constitute a representative sample of the kind and proportion of dart points that can be found on Archaic and Woodland period sites in the East Texas Pineywoods and Post Oak Savannah, it is clear that dart points of Late Archaic and Woodland period age dominate the sample (Figure 4). Points dating to these two periods comprise more than $83 \%$ of the large collection.

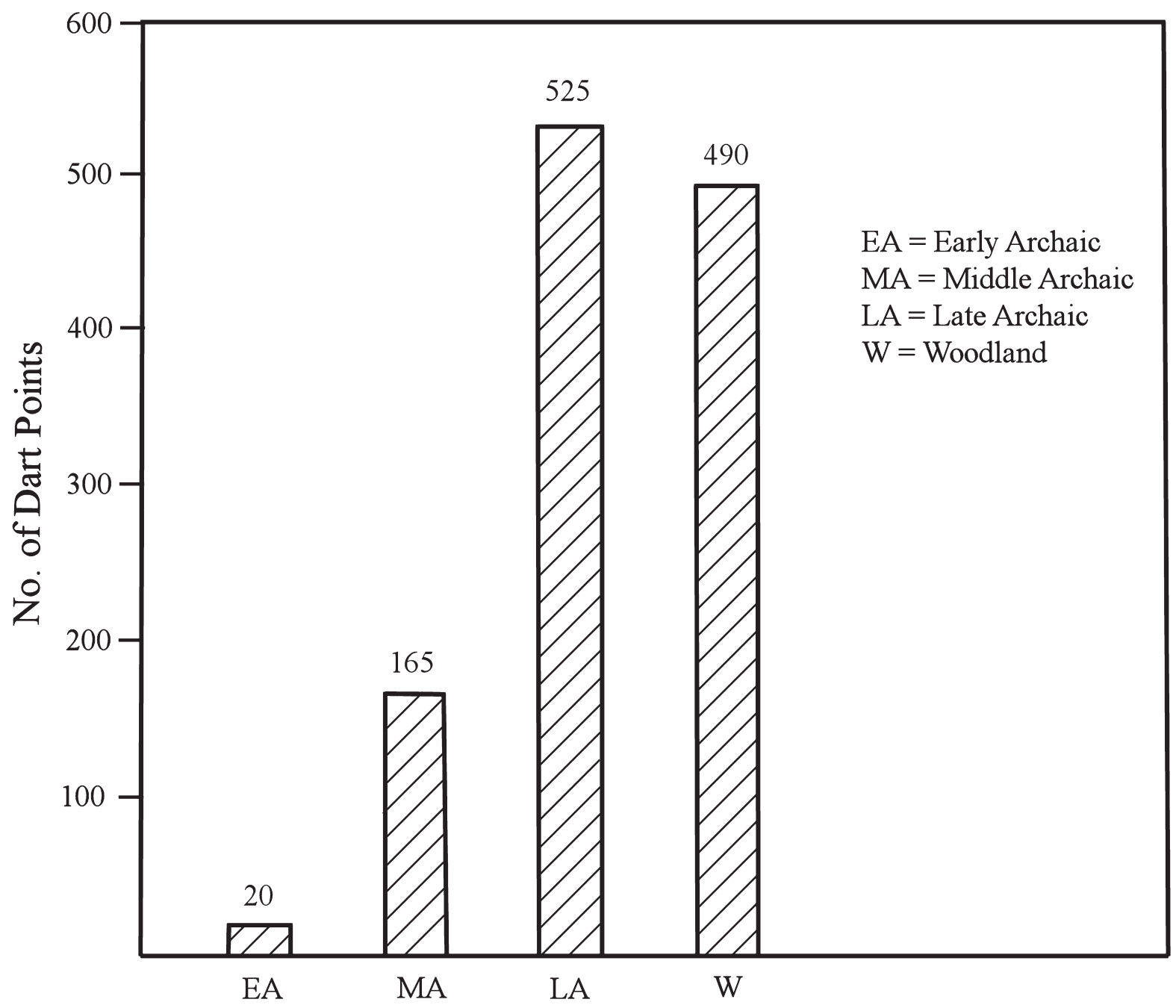

Figure 4. The Number of Dart Points Identified by Archaic and Woodland Time Periods. 
The Early Archaic points represent less than 2\% of the dart point collection. The principal dart points for this period include Dalton, San Patrice, and Scottsbluff. Middle Archaic dart points account for about $14 \%$ of the Jones framed dart point collection (see Figure 4). The best represented Middle Archaic dart point types in the collection include Morrill (40\%), Cossatot (20\%), Calf Creek/Bell/Andice (12\%), and White River (8\%). This suggests the main period of Middle Archaic settlement and use in this part of the East Texas Pineywoods and Post Oak Savannah took place after 6500 years B.P.

Late Archaic dart points are particularly well represented in the Jones framed dart point collection (see Figure 4). They represent almost $44 \%$ of the entire sample. The most common Late Archaic dart points are Yarbrough (34\%), Wells (18\%), Ellis (13\%), Williams (8\%), and Edgewood (6.9\%). Based on the temporal considerations discussed above, the range of common Late Archaic dart points suggests a continuous use of the East Texas Pineywoods and Post Oak Savannah throughout this period.

Finally, Woodland period points represent $41 \%$ of the studied dart point sample (Figure 4). These points include Gary (76\%) and Kent (24\%) dart points in the Jones collection.

If we convert the number of dart points from each Archaic period as well as the Woodland period to the number of dart points per century in the sample, we have an index that measures settlement use and intensity for each of the periods compared to one another (Figure 5). This index clearly demonstrates that the most intensive use of the East Texas Pineywoods and Post Oak Savannah as measured by projectile point numbers was by Woodland and Late Archaic hunter-gatherers. In fact, the intensity of use increased substantially between the Late Archaic and the Woodland period, suggesting that population size (and numbers of sites) continued to increase in the region after 2500 years B.P.

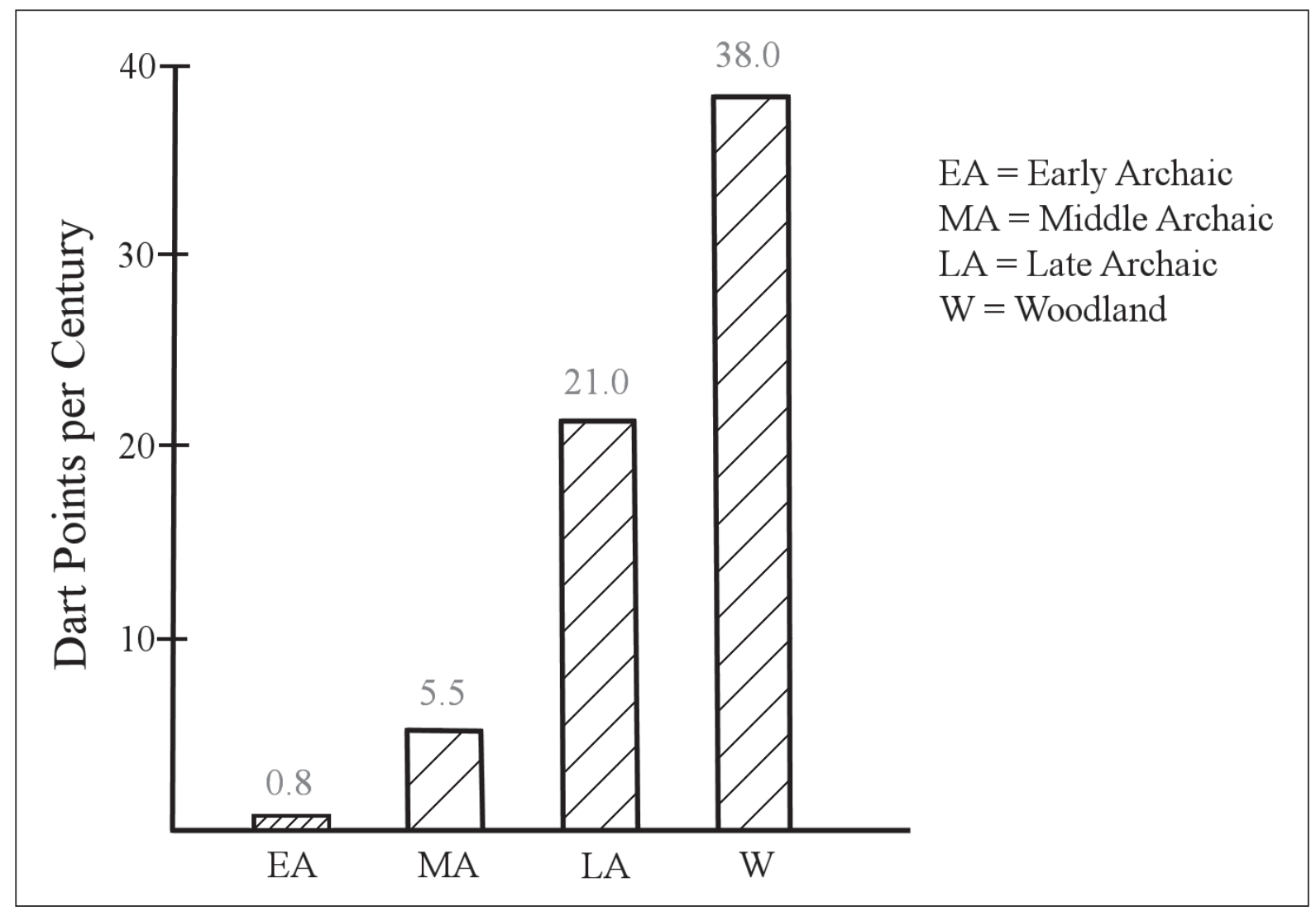

Figure 5. Dart Points per Century in the Archaic and Woodland Time Periods. 
The number and types of Early Archaic and Middle Archaic dart points/per century in our sample testify to a light use of the landscape during the 8000-10,000 years B.P. period, as well as from ca. 65008000 years B.P. (see Figure 5), with more use after 6500 years B.P. The number of Late Archaic dart points per century increased almost $400 \%$ over that of the Middle Archaic period as a whole.

We suspect that these broad trends in the use of the East Texas Pineywoods and Post Oak Savannah by hunter-gatherer groups over a 7500 year period, as tracked by projectile point frequencies and proportions per century in our dart point sample, reflect cultural and demographic changes and technological adjustments and adaptations associated with major climatic changes in the region, particularly in temperature and available precipitation, just as they do in other parts of North America (e.g. Collins et al. 2011; Munoz et al. 2010). By the onset of the Late Archaic, changes in the distribution of prairie and forest areas, due to generally wetter conditions after ca. 5000 years B.P. than was the case during the preceding Middle Archaic period, were much as they are in modern times. The known distribution, availability, and predictability of food resources in the region at this time apparently led to a substantial increase in American Indian population sizes that continued through the Woodland period and into the post-A.D. 800 Caddo periods.

\section{ACKNOWLEDGEMENTS}

Perttula would like to acknowledge the yeoman services provided by Bill Young, now deceased, in sorting the projectile point types from about 20 frames of dart points in the Buddy Jones collection. Perttula had initially requested that Bill take a look at the frames, and help with the identification of any Early Archaic points on them, but Bill was determined to typologically identify all the points on the frame, no matter how many Gary points were on each of them. He doggedly made his way through the frames, and he was working on them shortly before his death.

We would also like to acknowledge the assistance of Patti Haskins of the Gregg County Historical Museum for providing digital images of the dart point frames. Patti also provided permission for us to use two of the images in this article.

\section{REFERENCES CITED}

Carpenter, S. and P. Paquin

2010 Towards a Genealogy of Texas Stone Projectile Points. Bulletin of the Texas Archeological Society 81:153-175.

Collins, M. B. (assembler and editor)

1998 Wilson-Leonard: An 11,000-year Archeological Record of Hunter-Gatherers in Central Texas, Volume I: Introduction, Background, and Synthesis. Studies in Archeology 31, Texas Archeological Research Laboratory, The University of Texas at Austin, and Archeology Studies Program, Report 10, Texas Department of Transportation, Environmental Affairs Division, Austin.

Collins, M. B., D. M. Yelacic, and C. B. Bousman

2011 "Realms," A Look at Paleoclimate and Projectile Points in Texas. Bulletin of the Texas Archeological Society 82:3-30.

Furman, E. and C. Amick

2005 Archaeological Investigations at 41AN115. Journal of Northeast Texas Archaeology 21:15-63.

Girard. J. S.

2000 Regional Archeology Program Management Unit 1, Eleventh Annual Report. Northwestern State University of Louisiana, Natchitoches. 
Girard, J. S., N. Heller, J. P. Dering, S. L. Scott, H. E. Jackson, and G. L. Stringer

2011 Investigations at the Conly Site, a Middle Archaic Period Settlement in Northwest Louisiana. Louisiana Archaeology 32:5-77.

Jones, B. C.

1957 The Grace Creek Sites, Gregg County, Texas. Bulletin of the Texas Archeological Society 28:198231.

Koldehoff, B. and J. A. Walthall

2009 Dalton and the Early Holocene Midcontinent: Setting the Stage. In Archaic Societies: Diversity and Complexity across the Midcontinent, edited by T. E. Emerson, D. L. McElrath, and A. C. Fortier, pp. 137-151. State University of New York Press, Albany.

Lipo, C. P., M. J. O’Brien, M. Collard, and S. J. Shennan (editors)

2006 Mapping Our Ancestors: Phylogenetic Approaches in Anthropology and Prehistory. AldineTransaction, New Brunswick, New Jersey.

Munoz, S. E., K. Gajewski, and M. C. Peros

2010 Synchronous environmental and cultural change in the prehistory of the northeastern United States. Science 107(51):22008-22013.

O'Brien, M. J. and R. L. Lyman

2003 Cladistics and Archaeology. University of Utah Press, Salt Lake City.

Ray, J. H. and N. H. Lopinot

2003 Middle Archaic Components and Chert Use at the Bass Site. Missouri Archaeological Society Quarterly 20(2):4-16.

Ray, J. H., N. H. Lopinot, and E. R. Hajic

2009 Archaic Prehistory of the Western Ozarks of Southwest Missouri. In Archaic Societies: Diversity and Complexity across the Midcontinent, edited by T. E. Emerson, D. L. McElrath, and A. C. Fortier, pp. 155-197. State University of New York Press, Albany.

Rees, M. A.

2010 Paleoindian and Early Archaic. In Archaeology of Louisiana, edited by M. A. Rees, pp. 34-62. Louisiana State University Press, Baton Rouge.

Rogers, R. and T. K. Perttula

2004 The Oak Hill Village Site (41RK214), Rusk County, Texas. Document No. 030083. PBS\&J, Austin.

Saunders, J.

2010 Middle Archaic and Watson Brake. In Archaeology of Louisiana, edited by M. A. Rees, pp. 6377. Louisiana State University Press, Baton Rouge.

Schambach, F. F.

1998 Pre-Caddoan Cultures in the Trans-Mississippi South: A Beginning Sequence. Research Series 53. Arkansas Archeological Survey, Fayetteville.

Story, D. A.

1990 Cultural History of the Native Americans. In The Archeology and Bioarcheology of the Gulf Coastal Plain, by D. A. Story, J. A. Guy, B. A. Burnett, M. D. Freeman, J. C. Rose, D. G. Steele, B. W. Olive, and K. J. Reinhard, pp. 163-366. 2 Vols. Research Series No. 38. Arkansas Archeological Survey, Fayetteville. 
Thurmond, J. P.

1990 Archeology of the Cypress Creek Drainage Basin, Northeastern Texas and Northwestern Louisiana. Studies in Archeology 5. Texas Archeological Research Laboratory, The University of Texas at Austin.

Trubitt, M. B.

2009 Investigating Middle Archaic at the Jones Mill Site. The Arkansas Archeologist 48:71-84.

Turner, E. S. and T. R. Hester

1999 A Field Guide to Stone Artifacts of Texas Indians. Gulf Publishing/Rowman \& Littlefield Publishers, Inc., Lanham, Maryland.

Turner, R. L., Jr.

2006 Hematite Axes of Northeast Texas. Bulletin of the Texas Archeological Society 77:1-31.

Webb, C. H.

2000 Stone Points and Tools of Northwestern Louisiana. 2nd Edition. Special Publication No. 1. Louisiana Archaeological Society, Baton Rouge. 